\title{
GENDER, ISLAM DAN HAK ASASI MANUSIA
}

\author{
Oleh : Abd. Azis
}

\section{Abstract}

The new problem but last is the misinterpretation of gender, which is caused by social constructions, law, politic and religion. Its cause one of sexes, recently called gender, marginalized and subordinated. Women and men were not placed as human being who have the same opportunities and equalities in the public roles, law, education, and religion. All of the causes we called bias gender in whole our life, so that we must take forward in reinterpretation of it. Our God never treats the differences His prayers, the differentiation between women and men is only based on roles each others and quality of faith. Subordination, marginalization, molestation and discrimination are broken of human rights itselfand religion.

إن هذا ألبحك يكاول عرض مسألة تأحذ حيز من الأهية في الوقت الملاضر حول نحطا

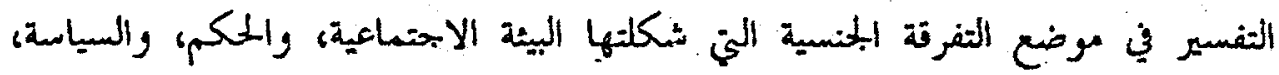
والأديان ـ الشيء الوحيد الذي يسببه هو الجنس وما يطلق عليه في التفرقة المنسية والتي

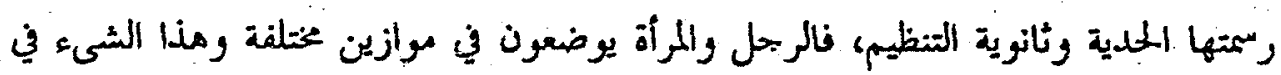

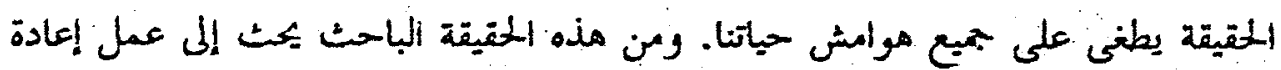

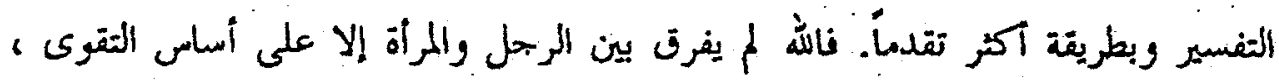
فالتهريق الملنسي هو انتهاك لمقوق الإنسان الأساسية والدين.

Keywords : Gender, Islam, Reinterpretasi, Hak Asasi Manusia

\footnotetext{
-Penulis Mahasiswa Program Pascasarjana Universitas Negeri Yogyakarta.
} 


\section{A. Pendahuluan}

Denafsiran yang "kurang tepat" terhadap suatu fenomena sosial adalah suatu hal yang wajar, karena ini akan merangsang suatu wacana baru yang debatable dan selama penafsiran itu tidak membawa kepada pereduksian hakhak asasi manusia. Terhadap penafsiran makna gender (the interpretation of gender) misalnya, yang justru kebanyakan membuat salah satu jenis kelamin manusia baik kehormatan, derajat, martabat, keadilan menjadi tereliminir. Banyak orang menyepelekan hal ini sebagai sesuatu yang alami (natural) yang berlaku dalam suatu komunitas sosial. Sehingga ketidakadilan dan ketidaksamaan peran seakan tampak legitimated, absah. Legitimasi ini lebih disebabkan dan dibangun atas persepsi-persepsi sosial dengan segala interpretasi dan tendensinya melalui komunikasi dan sosialisasi yang panjang sebagai wujud kelanjutan dari mekanisme-mekanisme yang menjadi mesin pelanggengan konstruksi sosial terhadap makna gender itu sendiri, dan terkonfigurasi dalam produk sosial, hukum, politik, maupun agama.

\section{B. Bentuk-Bentuk Pelanggengan Bias Gender}

Mekanisme "pelánggengan" tafsir bias gender ini tisa melalui pelbagai cara seperti, pertama, melalui sosialisasi makna gender yang keliru pada laki-laki dan perempuan, sehingga membentuk paradigma tersendiri bagi kalangan lakilaki dan perempuan bahwa terdapat perbedaan kodrati yang kebenarannya absolut dan tidak perlu dipersoalkan sebagai sesuatu yang bersifat profan. Kedua melalui konstruksi sosial yang diperkuat dengan campur tangan interpretasi kalangan agamawan yang sering kali menuruti keinginan-keinginan pribadi (vested interest) yang didasarkan pada keuntungan kelas-kelas sosial maupun ekonomi. Ulama atau darwis dalam Islam, lewi dalam Yahudi, pendetapastur, romo dalam Kristen-Katholik, menampakkan peran-peran sebagai penafsir utama dalam agama melebihi kapasitasnya sebagai penafsir agama yang sesungguhnya. Sehingga apa yang disebut Weber sebagai agama kelaskelas tanpa hak istimewa yang disifati oleh tendensi eksklusifitas pada wanita hampir menjadi kenyataan. Suatu misal, perbedaan besar terdapat dalam bidang partisipasi religius yang dibolehkan pada kaum wanita dalam partisipasinya yang bersifat pasif.' Setidaknya dua hal di atas ini yang menurut penulis menjadi alasan kalangan pejuang feminisme untuk melawannya seperti feminisme liberal, radikal, marxis, sosialis sampai pada aliran terkini yaitu poststrukturalis.

\section{Perspektif Feminisme}

Dalam perspektif feminisme sosialis yang lebih menekankan pada sintesa pemikiran Friedrich Engels dan Karl Marx, penindasan dapat terjadi pada kelas manapun, aliran ini menggabungkan analisis patriarkhi dan analisis kelas. Bagi hal. 152

'Max Weber, 1962. The Sociology of Religion, alih bahasa M. Yamin, 2002, Yogyakarta: IRCiSoD, 
cminisme sosialis ketidakadilan bukan disebabkan oleh perbedaan biologis untara laki-laki dan perempuan, melainkan karena anggapan dan penilaian riasyarakat (social construction) terhadap perbedaan itu. ${ }^{2}$ Sebaliknya bagi Jeminisme Marxis bahwa persoalan perempuan selalu diletakkan pada kerangka kritik atas kapitalisme. ${ }^{3}$ Bagi feminisme Marxis penindasan perempuan merupakan kelanjutan dari eksploitasi yang bersifat struktural, dan sistem kapitalisme sebagai penyebabnya. Maka penyelesaiannya harus bersifat struktural dengan merubah struktur kelas dan pemutusan hubungan dengan sistem kapitalisme internasional.

Paradigma biologis dijadikan argumentasi oleh kalangan feminisme radikal dalam memperjuangkan keadilan dan kesejajaran perempuan dengan laki-laki. Paham dan analisis mereka bahwa personal is political, memberi peluang politik bagi kaum perempuan. ${ }^{5}$ Ada beberapa persoalan yang menjadi karakter perjuangan feminisme radikal yaitu: pertama, konsep patriarkhi yang dipakai untuk menganalisis prinsip-prinsip penindasan perempuan. Seperti yang. diargumentasikan oleh Millett (1971) bahwa patriarkhi merupakan analitically independent of capitalist or modes of production. Firestone (1970) mendefinisikan patriarkhi dalam term-term penguasaan laki-laki terhadap reproduksi perempuan. ${ }^{6}$ Nickie Charles (1993) mengatakan bahwa yang disebut dengan patriarkhi adalah dominasi secara keseluruhan tatanan laki-laki atas semua perempuan. ${ }^{7}$

Kedua, asumsi kaum feminis radikal bahwa penindasan universal perempuan (universal oppression of women) dilahirkan oleh laki-laki yang menindas perempuan, dan perempuan sebagai kelas yang tertindas (the oppressed class) yang mempunyai keterkaitan dengan budaya patriarkhi yang diciptakan dan terus menerus dipertahankan. Firestone (1970) berargumentasi bahwa ketidaksamaan fundamental antara laki-laki dan perempuan dapat ditelusuri pada realitas fisik perempuan dan realitas biologis laki-laki (yang mempunyai fungsi reproduksi sendiri-sendiri) dan konsekuensi-konsekuensi mereka.

Ketiga, yaitu penyadaran terhadap efek-efek dominasi laki-laki, perempuan harus menjalani sebuah proses pengenalan pendidikan yang difokuskan pada

\footnotetext{
${ }^{2}$ Mansour Fakih, 2001, Analisis Gender dan Transformasi Sosial, Yogyakarta: Pustaka Pelajar, hal.92

${ }^{3}$ Ibid., hal. 86

"Ibid., hal. 88-89

"Ibid., hal. 86. Lihat, B. Davies, 1994, "Gender Theories in Education," dalam Torsten Husén dan T. Neville Postlethwaite, The International Encyclopedia of Education, second edition, Volume V, Oxford: Elsevier Ltd., hal. 2453.

${ }^{6}$ Gaby Weiner, 1994, Feminism in Education: An Introduction, Buckingham Philadelpia: Open University Press, hal. 54-55.

'Nickie Charles, 1993, Gender Divisions and Social Change, Harvester. Wheatsheaf, Bames and Noble Books. hal.88.
} 
perempuan atau reeducation sebagai bentuk peningkatan penyadaran (consciousness raising). Consciousness raising dimaknai sebagai tukar informasi (sharing information) tentang pengalaman perempuan dan juga dimaknai sebagai pendidikan untuk perempuan karena kurangnya perempuan dalam pengetahuan dasar yang komprehensif. ${ }^{8}$ Suatu misal, ketika wacana kepemimpinan diangkat kepermukaan dan dikorelasikan dengan peran perempuan, akan muncul suatu resistensi dari kalangan "agamawan klasik" bahwa perempuan tidak layak memimpin dibandingkan laki-laki sebab dalam aktivitasnya perempuan akan banyak mengalami hambatan biologis yang menjadi rintangan peran-perannya seperti haid, melahirkan dan mendidik anak. Pada term terakhir ini dikalangan masyarakat kita telah terbangun satu paradigma yang "semi kokoh" bahwa pendidikan anak merupakan tanggung jawab perempuan an sich, sedangkan laki-laki merasa terbebas untuk memikul tanggung jawab itu, mengapa harus perempuan? Bukankah ia telah berjuang selama delapan hingga sembilan bulan untuk anak itu? Dari persepsi seperti ini aliran feminisme radikal mengatakan bahwa kesejajaran antara laki-laki dan perempuan hanya akan tercapai ketika peran-peran domestik perempuan hilang darı digantikan dengan peran-peran publik. Untuk urusan memasak, mencuci dan mendidik anak menjadi tanggung jawab sosial.

Perspektif lain dari mekanisme peletakan perbedaan laki-laki dan perempuan yang berdasarkan kesifatan, yaitu feminisme liberal. Tesis feminisme liberal berakar pada pandangan bahwa kebebasan (freedom) dan kesamaan (equclity) berakar pada rasionalitas dan pemisahan antara dunia privat dan publik. Kerangka kerja feminisme liberal adalah kesempatan yang sama dan hak yang sama. Asumsinya, karena perempuan adalah makhluk rasional juga.' Anggapan ini lahir karena konstruksi sosial dan kultural dalam masyarakat kita. Bahwa perempuan itu harus lemah lembut, penyayang, keibuan sedangkan laki-laki perkasa, kuat dan melindungi.

Muncul suatu pertanyaan akankah seorang perempuan bisa bersifat dan bersikap seperti laki-laki kalau dididik seperti kaum laki-laki? Bagi kalangan tradisionalis tidak mungkin, secara lahiriah laki-laki dan perempuan berbeda dan ini akan membawa kepada perubahan dan perbedaan sifat pada masingmasing jenis kelamin tersebut dan tidak boleh terjadi, sebab menyalahi ketentuan hukum sosial, suatu produk hukum yang dikonstruk oleh masyarakat yang tidak tertulis dan menjadi konsensus bersama. Bagi kalangan non tradisional hal itu mungkin terjadi, sebab eksistensi laki-laki dan perempuan tidak ditentukan oleh determinasi biologis dan sifat secara ketat, melainkan peranan dan tanggungjawab mereka secara sosial. Suatu contoh banyak lakilaki yang berwajah dan bersikap seperti perempuan, lemah lembut dan

\footnotetext{
${ }^{8}$ Ibid., hal. 55

'Mansour Fakih, ibid., hal.81-82.
} 
berdandan seperti perempuan, juga ada perempuan yang berlagak seperti lakilaki perkasa seperti Laila Ali sang petinju atau Lisa Rumbewas sang lifter. Determinasi biologis dan sifat secara berlebihan dan anggapan kuat tidaknya seseorang tidak terletak pada kekuatan ototnya, tapi pada otaknya.

Dalam pandangan feminisme poststrukturalis; Simone De Beauvoir dalam bukunya The Second Sex (1952/1974) mendiskusikan bagaimana antara lakilaki dan perempuan dimaknai secara dikotomi, laki-laki didefinisikan sebagai "The Self" dan perempuan sebagai "The Others". Menurutnya ini bukan saja pembedaan dari kaum laki-laki melainkan juga sebagai bentuk perendahan. ${ }^{10}$ Kaum feminis poststrukturalis selain menfokuskan pada solusi-solusi individu, juga mempersoalkan bahwa inti penindasan adalah bersifat struktural, diskriminasi ekonomi misalnya." Bentuk-bentuk pelanggengan ini semakin dikuatkan dan dikuatkan kembali. Ketidakterhindaran kontradiksi, yang telah memberikan diskursus yang bersifat kontradiktif dan pemposisian-pemposisian dalam diskursus melalui teori-teori, secara terus menerus dikuatkan (constituted) dan dikuatkan kembali (reconstituted). ${ }^{12}$ Batasan-batasan seorang perempuan dalam bentuk masyarakat patriarkhi menempatkan wanita dalam posisi yang kurang menguntungkan.

\section{Perspektif Islam dan HAM}

Bentuk mekanisme berikut terhadap pemaknaan gender yang keliru dibangun atas interpretasi agama. Kebanyakan para kalangan agamawan klasik mengartikulasikan ayat-ayat demi kepentingannya sendiri, agar tidak tersaingi. Mereka selalu mengkhotbahkan surat An-nisa' ayat 13 yang menyatakan "bahwa laki-laki adalah penuntun bagi perempuan". Terkesan penafsiranpenafsiran seperti ini dipolitisir demi melanggengkan apa yang disebut oleh Charol Shakeshaft sebagai wujud androcentism yaitu dominasi laki-laki dalam ilmu pengetahuan dan research. ${ }^{13} \mathrm{Hal}$ ini menandakan bahwa dogma atau kepercayaan agama, khususnya syari'at Islam merupakan kerangka yang "dingin" dan berpengaruh secara kausal dimana hubungan dan kegiatan sosial berlangsung, termasuk dalam relasi laki-laki dan perempuan. Weber menyebutnya dengan dominasi patrimonial yang berbuat sekehendak hatinya dan tak dapat diperkirakan dari semula mempunyai hasil memperkuat lingkungan ketaatan pada hukum. ${ }^{14}$ Dominasi patrimonial ini membawa ekses

\footnotetext{
10 J.O Burger and Helen A.More, 1992, A Sociology of Women, The Intersection of Patriarchy, Capitalims and Colonization, New Jersey: Printice Hall, Englewood Cliffs, hal. 25

"Ibid., hal. 25

B. Davies, op.cit. hal. 2457

Charol Shakeshaff, 1987, Women in Education Administration, Newbury Park, CA: Sage Publications, Inc. hal. 150

${ }^{13}$ Max Weber, 1968, Economy and Society, Volume 3, (Gunther Roth and Claus Wittich, eds); New York, hal. 1096

"Universal Declaration of Human Rights 1948, Pasal I
} 
kepada ketidakseimbangan tatanan politik, ekonomi, pendidikan, hukum, dan agama serta melahirkan apa yang kita namakan sekarang dengan budaya marginalisasi dan subordinasi terhadap salah satu jenis kelamin itu.

Dalam pandangan hukum HAM, setiap manusia di dunia tanpa melihat ras, suku, warna kulit, agama, dan kebangsaan mempunyai hak-hak asasi yang sama. Tidak ada yang lebih tinggi, pun tidak ada yang lebih rendah, semua dalam kesejajaran, kesederajatan, tidak ada bentuk diskriminasi, baik hak berkumpul, berpendapat, pelecehan, berprofesi, memerankan peran-peran publik dan ini berlaku bagi jenis kelamin laki-laki dan perempuan. Argumentasinya adalah, karena "semua orang dilahirkan merdeka dan mempunyai martabat dan hak-hak yang sama. Mereka dikaruniai akal dan budi dan hendaknya bergaui satu sama lain dalam persaudaraan". ${ }^{\text {.5 }}$ Dalam Deklarasi Kairo Hak Asasi Manusia dalam Islam pasal 1 dinyatakan bahwa:

semua umat manusia merupakan satu keluarga yang para anggotanya dipersatukan oleh ketaatan kepada Allah dan bahwa mereka adalah keturunan Adam. Semua orang adalah sama dipandang dari martabat dasar manusia dan kewajiban serta tanggung jawab dasar mereka, tanpa diskriminasi ras, warna kulit, bahasa, jenis kelamin, kepercayaan agama, ideologipolitik, status sosial atau pertimbangan-pertimbangan lain. ${ }^{16}$

Oleh sebab itu segala bentuk diskriminasi, pelecehan, dan penghambatan terhadap peran-peran publik perempuan merupakan bentuk pelanggaran atas hak asasi manusia. termasuk di dalamnya adanya kecenderungan pereduksian makna dan interpretasi yang kurang tepat akan istilah gender.

Pada perubahan kedua UUD 1945 pasal 28 I ayat 2 dinyatakan bahwa "setiap orang berhak bebas dari perlakuan yang bersifat diskriminatif atas dasar apa pun dan berhak mendapatkan perlindungan terhadap perlakuan yang bersifat diskriminatif itu". ${ }^{17}$ Dalam konvensi mengenai penghapusan segala bentuk diskriminasi terhadap perempuan (CEDAW), pasal I dinyatakan bahwa yang dimaksud dengan diskriminasi perempuan adalah pembedaan, pengucilan, atau pembatasan yang dibuat atas dasar jenis kelamin, yang berakibat dan bertujuan untuk mengurangi atau menghapuskan pengakuan, penikmatan atau penggunaan hak-hak asasi manusia dan kebebasan-kebebasan pokok di bidang politik, ekonomi, sosial budaya, sipil atau apapun lainnya oleh kaum perempuan, terlepas dari status perkawinan mereka, atas dasar persamaan antara laki-laki dan perempuan. ${ }^{18}$ Dalam deklarasi penghapusan kekerasan terhadap perempuan pasal 1, bahwa yang dimaksud dengan kekerasan terhadap

\footnotetext{
${ }^{15}$ The Cairo Declaration on Human Rights in Islam, Pasal 1

${ }^{16}$ Bagir Manan, 2001, Perkembangan Pemikiran dan Pengantar HAM di Indonesia, Bandung: Yayasan HAM, Demokrasi dan Supremasi Hukum, hal. 127.

${ }^{71}$ Kumpulan Perangkat HAM Internasional, 2001, CHRF-INSIST Educator HAM Kalimantan, hal. 48.

${ }^{18}$ Ibid., hal. 196.
} 
nerempuan adalah setiap tindakan berdasarkan perbedaan jenis kelamin yang berakibat atau mungkin berakibat kesengsaraan atau penderitaan perempuan secara fisik, seksual dan psikologi, termasuk ancaman tindakan tertentu, pemaksaan atau perampasan kemerdekaan secara sewenang-wenang; baik yang terjadi di depan umum atau dalam kehidupan pribadi. ${ }^{19}$

Pemaknaan terhadap kekerasan dapat berupa fisik dan non fisik. Kekerasan fisik dapat berupa pelecehan dan kekerasan seksual (sexual violence and harrasment), pemukulan, pembunuhan dan lain-lain. Kekerasan yang berupa non fisik adalah bentuk-bentuk intimidasi, pengucilan, subordinasi, marginalisasi, inferiorisasi dan hal-hal yang dapat membuat harkat dan martabat perempuan jatuh. Perempuan dan laki-laki adalah setara dalam martabat sebagai manusia, dan mempunyai hak yang dinikmati ataupun kewajiban yang dilaksanakan, ia mempunyai kapasitas sipil dan kemandirian keuangannya sendiri, dan hak untuk mempertahankan nama baik dan keturunannya. ${ }^{20}$

Pendiskriminasian dan apapun bentuknya adalah suatu pelanggaran HAM, sebab kenyataan universal dalam hukum, persamaan antara laki-laki dan perempuan dijamin oleh undang-unidang. Suatu misal penempatan kaum perempuan secara ekslusif dan menganggap mereka lebih lemah daripada kaum laki-laki. Dalam diskursus gender, persoalan ketidakadilan perlakuan terhadap wanita seringkali dipandang dinomerduakan dari tingkat domestik atau rumah tangga, karena tidak adanya keseimbangan antara hak dan kewajiban suami dan istri. Pada konteks ini, pasal 51 UU Nomor 39 Tahun 1999 menegaskan secara rinci bahwa "seorang istri selama dalam ikatan perkawinan mempunyai hak dan kewajiban yang sama dengan suaminya atas semua hal yang berkenaan dengan kehidupan perkawinannya, hubungan dengan anak-anaknya dan hak pemilikan serta pengelolaan harta bersama." 21

Problem utama dalam implementasi hukum HAM adalah tidak banyak menyangkut permasalahan-permasalahan domestik secara riil, karena dianggap sebagai privasi individu. Kalau kita mau jujur mengatakan bahwa keluarga adalah komunitas kecil yang menjadi simbol-simbol dari sebuah komunitas yang besar yaitu masyarakat secara keseluruhan. Sehingga, kekerasan yang dilakukan oleh suami terhadap istri dan anak-anaknya, suatu misal, hampir tidak tersentuh oleh perangkat hukum HAM. Hal ini berjalan secara natural dan nurtural. Natural berarti perbedaan peran laki-laki dan perempuan bersifat kodrati. Anatomi perbedaan biologis menjadi faktor utama dalam menentukan peran sosial. Laki-laki dianggap mempunyai peran utama dalam masyarakat

\footnotetext{
${ }^{19}$ The Cairo Declaration on Human Rights in Islam, Pasal 6

${ }^{20}$ Bagir Manan, op.cit., 147

${ }^{21}$ Komaruddin Hidayat (pengantar), 1999, Tafsir Kebenciar, Studi Bias Gender Dalam Al-Qur'an, Yogyakarta:LKis, hal.xvii.
} 
karena dianggap potensial dan lebih produktif. ${ }^{22}$ Ini berimbas pada kesewenangwenangan laki-laki terhadap perempuan dalam sebuah rumah tangga, sebab perempuan terbatasi ruang geraknya. Secara nurtural adalah suatu anggapan bahwa perbedaan peran antara laki-laki dan perempuan muncul dari relasi-relasi laki-laki dan perempuan yang tidak didasarkan pada biologis, melainkan hasil konstruksi masyarakat. ${ }^{23}$ Jadi bisa terjadi bias-bias dalam penafsiran makna gender yang sebenarnya dalam suatu masyarakat yang dianggap sebagai sebuah ketentuan agama.

Dalam surat al-Hujurat ayat 13 disebutkan bahwa kedudukan antara laki-laki dan perempuan sama. ${ }^{24}$ Dalam peran-peran sosial, seperti memutuskan perceraian atau ishlah, wanita mempunyai hak yang sama dengan laki-laki.(alBaqarah ayat 228). ${ }^{25}$ Pada ayat yang lain yaitu surat al-Baqarah ayat 232 diindikasikan bahwa perempuan bebas memilih calon suami yang akan dipilihnya. ${ }^{26}$ Ini menjadi bagian dari HAM perempuan yaitu pada pasal 16 ayat 1,2 dan 3. Pada ayat pertama disebutkan

laki-laki dan perempuan yang telah dewasa, tanpa pembatasan atas dasar perbedaan ras, kebangsaan dan agama mempunyai hak untuk menikah dar: mendirikan rumah tangga. Mereka mempunyai hak yang sama dalam pernikahan, selama pernikahan masih berlangsung dan waktu perceraian. ${ }^{27}$

Dalam Deklarasi Kairo tentang Hak-hak Asasi dalam Islam, pada pasal 5 disebutkan bahwa "laki-laki dan wanita mempunyai hak untuk menikah, dan tak ada larangan yang bersumber dari ras, warna kulit atau kebangsaan untuk menikmati hak ini'. ${ }^{28}$

Jadi jelas sudah bahwa bentuk-bentuk pendiskriminasian, kekerasan terhadap perempuan merupakan pelanggaran terhadap HAM dan agama. Namun anehnya kalangan agamawan muslim masih terpaku pada surat an-Nisâ' ayat 13 yang menyatakan bahwa laki-laki adalah pemimpin, pelindung, penuntun bagi kaum perempuan. Padahal kata "Qowwâm" ini adalah musytarak atau ambigu, mempunyai banyak makna, yang secara implisit dapat dimaknai, "berdiri sejajar", "berperan sama", "berprofesi sama", "mempunyai tanggung jawab sama" dan "bekerja sama". Bentuk-bentuk tanggung jawab

\footnotetext{
${ }^{n}$ Ibid., hal. xix

${ }^{23}$ Artinya" Hai manusia sesungguhnya kami menciptakan kamu dari seorang laki-laki dan perempuan dan menjadikan kamu berbangsa-bangsa dan bersuku-suku supaya kamu saling mengenal. Sesungguhnya yang paling mulia disisi Allah adalah orang yang paling bertaqwa diantara kamu". baik"

${ }^{24}$ Artinya "...dan para wanita mempunyai hak yang sama dengan kewajibannya menurut cara yang

${ }^{35}$ Artinya "Apabila kamu mentalak istri-istrimu lalu habis iddahnya, maka janganlah (para wali) menghalangi mereka kawin lagi dengan bakal suaminya".

${ }^{2}$ Universal Declaration of Human Rights, Pasal 16

${ }^{27}$ The Cairo Declaration on Human Rights in Islam, Pasal 5

${ }^{28}$ Claire M. Renzetti dan Daniel J.Curran, 1992, Women, Men and Society, Singapore: Allyn and Bacon Toronto hal. 297.
} 
yang sama dengan laki diungkapkan oleh Carmody (1979) bahwa "women, like men, were expected to adhere to the five pillars of Islam, which include prayer five times a day and fasting during the holy month called Ramadan and they worshipped with men in the mosques". 29

Untuk mengeliminir tereduksinya hak-hak perempuan baik publik maupun domestik dalam perspektif agama diperlukan suatu penafsiran baru yang kontekstual demi kesederajatan dan keadilan diantara kedua jenis kelamin. Seperti yang diungkap oleh Higgens (1985)

today Islamic leaders maintain that men and women hold equal status, although they are quick to emphasize that this quality does not derive from sharing the same priveleges and responsibilities but rather from complementary of their roles. In this world view, men and women are equal before God, but they had somewhat diffirent physical, mental and emotional qualities, somewhat diffirent responsibilities in the family and society, and somewhat diffirent rights and prerogratives. ${ }^{30}$

\section{E. Kesimpulan}

Ada beberapa yang perlu kita jadikan perenungan dalam memperbincangkan relasi-relasi sosial antara laki-laki dan perempuan dalam peran-peran publik bahwa:

1. Keberadaan antara laki-laki dan perempuan dalam konstruk sosial manapun tetap menjadi diskursus yang terbedakan. Dan ini dikuatkan oleh konvensi sosial yang tak tertulis dan merupakan konsensus yang lebih-lebih didasarkan pada tafsir agama yang dogmatis sifatnya dan taken for granted. Solusinya yaitu melalui conciousness raising dikalangan perempuan dan penempatan-penempatan posisi-posisi strategis publik ditingkat struktur sosial, dalam institusi-institusi, hukum, pendidikan, politik, dan agama.

2. Bentuk-bentuk pendiskriminasian, subordinasi dan marginalisasi baik sosial máupun ekonomi adalah bagian dari pelanggaran hak asasi manusia dan agama, atas dasar apapun pelanggaran itu dirujuk dan di tingkat-tingkat komunitas sosial manapun terjadi baik keluarga, komunitas pers, politik, pendidikan maupun agama. Untuk mengeliminir bentuk-bentuk pelanggaran ini, tidak semata-mata mengkambinghitamkan laki-iaki sebagai penyebabnya, melainkan melalui sebuah pendidikan dengan penguasaan tingkat pengetahuan yang komprehensif bagi kalangan perempuan.

3. Dalam perspektif tafsir agama dibutuhkan interpretasi yang lebih egaliter dan elegan, yang menempatkan antara laki-laki dan perempuan dalam posisi yang sesungguhnya sebagai representasi kesederajatan umat manusia di hadapan Tuhan. Reinterpretasi tersebut tidak mereduksi sakralitas agama, lebih-lebih menempatkan agama pada yang profan:

${ }^{29}$ Ibid., hal. 297 


\section{DAFTAR PUSTAKA}

Burger, J.O and A.More, Helen, 1992, A Sociology of Women, The Intersection of Patriarchy, Capitalims and Colonization, New Jersey: Printice Hall, Englewood Cliffs.

Charles, Nickie, 1993, Gender Divisions and Social Change, Harvester Wheatsheaf: Barnes and Noble Books.

Davies, B., 1994, "Gender Theories in Education," dalam Torsten Husén dan T. Neville Postlethwaite, The International Encyclopedia of Education, second edition, Volume V, Oxford: Elsevier Ltd.

Depag RI, 1993, al-Qur'an dan Terjemahannya, Bandung: CV.Gema Risalah Press.

Fakih, Mansour, 2001, Analisis Gerder dan Transformasi Sosial, Yogyakarta: Pustaka Pelajar.

Hidayat, Komaruddin (pengantar), 1999, Tafsir Kebencian, Studi Bias Gender. Dalam Al-Qur'an, dalam Zaitunah Subhan, Yogyakarta: LKiS

Kumpulan Perangkat HAM Internasional, 2001, Pontianak 3-9 Juli, CHRFINSIST Educator HAM Kalimantan.

Manan, Bagir, 2001, Perkembangan Pemikiran dan Pengantar HAM di Indonesia, Bandung: Yayasan HAM, Demokrasi dan Supremasi Hukum.

Renzetti, Claire M. dan Curran, Daniel J., 1992, Women, Men and Society, Singapore: Allyn and Bacon Toronto.

Shakeshaff, Charol, 1987, Women in Education Administration, Newbury Park, CA: Sage Publications, Inc.

The Cairo Declaration on Human Rights in Islam 1990

Universal Declaration of Human Rights 1948

Weber, Max, 1962, The Sociology of Religion, alih bahasa M. Yamin, 2002, Yogyakarta: IRCiSoD

----, 1968, Economy and Society, Vol,3, Gunther Roth and Claus Wittich, eds New York.

Weiner, Gaby,1994, Feminism in Education: An Introduction, Buckingham Philadelpia: Open University Press. 